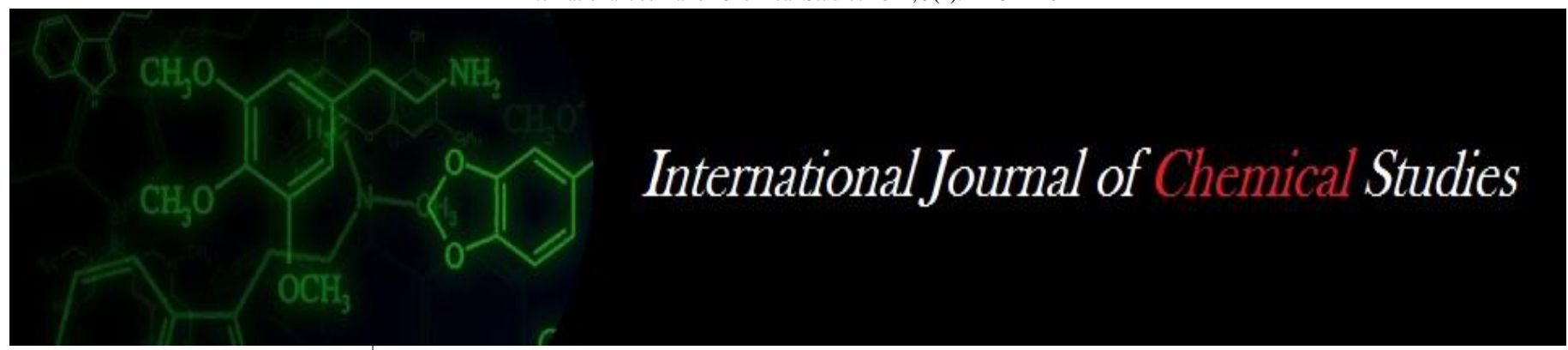

P-ISSN: 2349-8528

E-ISSN: 2321-4902

www.chemijournal.com

IJCS 2021; 9(1): 2123-2126

(C) 2021 IJCS

Received: 11-10-2020

Accepted: 21-11-2020

\section{Jainpal Rathore}

M.Sc. (Ag), Department of Plant

Pathology, Jawaharlal Lal

Nehru Krishi Vishwa Vidyalaya,

Jabalpur, Madhya Pradesh,

India

\section{Dr. KN Gupta}

Assistant Professor Scientist, PC Unit JNKVV, Jabalpur, Madhya Pradesh, India

\section{Babli Verma}

Ph.D., Research Scholar Department of Plant Pathology, Rajmata Vijayaraje Scindia Krishi Vishwa Vidyalaya, Gwalior, Madhya Pradesh, India

Dwarka Prasad Athya Ph.D., Research Scholar, Department of Entomology, Jawaharlal Lal Nehru Krishi Vishwa Vidyalaya, Jabalpur, Madhya Pradesh, India
Corresponding Author: Babli Verma

Ph.D., Research Scholar,

Department of Plant Pathology,

Rajmata Vijayaraje Scindia

Krishi Vishwa Vidyalaya,

Gwalior, Madhya Pradesh, India

\section{Effect of weather parameters on disease development of root and stem rot of sesame caused by Sesamum indicum $\mathrm{L}$.}

\author{
Jainpal Rathore, Dr. KN Gupta, Babli Verma and Dwarka Prasad Athya
}

DOI: https://doi.org/10.22271/chemi.2021.v9.i1ad.11534

\begin{abstract}
Sesame (Sesamum indicum L.) is an ancient oilseed crops cultivated in semi-arid Tropics and sub tropics regions in India. It play an important role in the oilseed economy throughout the world. The fungal disease root and stem rot caused by M. phaseolina (Tassi) Goid is the most important disease and is widely, distributed in sesame growing region. The pathogen attacks plant at all growth stages. Due to soil borne nature practically no effective field control and no source of resistant is available. So for the presented investigation entitled field experiment was also conducted with three date of sowing using susceptible cultivars VRI-1.Root and stem rot intensity was higher in all the three date of sowing. Correlation of disease with the weather parameter indicate that root and stem rot disease was negatively relationship with all weather parameter viz, maximum temperature, minimum temperature, rain fall $(\mathrm{mm})$, no of rainy days, relative humidity (morning and evening).
\end{abstract}

Keywords: Sesame, Macrophomina phaseolina, weather parameters

\section{Introduction}

Sesame (Sesamum indicum L.) is the oldest among the oilseeds crops cultivated in semi-arid tropics and sub tropics to temperate regions in India. Sesame which was originated in Africa is probably the most ancient oil seed plant cultivated in many parts of the world. Myanmar, India, China are the world's largest producers of sesame in the major sesame growing states are Uttar Pradesh, Rajasthan, Madhya Pradesh Chhattisgarh, Andhra Pradesh, Maharashtra, Gujarat, Tamil Nadu, West Wangal and Orissa Uttar Pradesh, Rajasthan, Madhya Pradesh or Chhattisgarh and contribute about half of the total sesame production of the country. However, a distressing feature is that the productivity of sesame in these states is very low. The main reason for low productivity of this crop is due to the attack of various weather factors and diseases, such as root and stem rot, Alternaria leaf spot (Alternaria sesame), Bacterial blight (Xanthomonas campestris pv. sesame), Powdery mildew (Erysiphe cichoracearum), Cercospora leaf spot (Cercospora sesame) and phyllody (Mycoplasma) Gupta et al (2018) [5]. Stem and root rot is caused by (M. phaseolina) is one of the important diseases of this crop all over the world (Rajput et al., 1998; Dinakaran and Mohammed, 2001) ${ }^{[8,4]}$. It is very serious and destructive in all sesame growing areas and cause $5-100 \%$ yield loss and $57 \%$ yield loss at about $40 \%$ of disease incidence (Vyas and Patel, 1981) ${ }^{[10]}$. The pathogen attacks root stem, leaf, pod and seeds (Mukharji and Bhasin, 1986) ${ }^{[7]}$. The most common symptoms of the disease is sudden wilting of growing plant mainly after the flowering stage, stem portion near the ground level show dark brown and dark black lesion at the collar region show shreding and to destroy the vascular bundles by causing the plant death. Stem portion can be easily pulled out leaving the rotten rot portion in the soil (Avila et al., 1999) ${ }^{[1]}$. Macrophomina phaseolina is a seed and soil borne pathogen causing root and stem rot on sesame crops. The disease is veryimportant as infection occurs from seed germination and emergence to adult stage. $M$. phaseolina is an important phytho pathogen distributed worldwide and causes charcoal rot on more than 500 plant species (Das et al., 2008) ${ }^{[2]}$ It is a mithosporic 2 fungal species (Menezes and Oliveira, 1993) ${ }^{[6]}$. It is a member of Phylum-Deteromycetes, Class-Coelomycetes, OrderSphaeropsidales, Family Sphaeropsidaceae. Pycnidia are 100-200 $\mu \mathrm{m}$ in diameter, dark brown to greyish, becoming black with age, globose or flattened globose, membranous to sub carbonaceous with an inconspicuous or definite truncate ostiole. 
The pycnida bear simple, rod-shaped conidiophores, 10-15 $\mu \mathrm{m}$ long. Conidia are $14-33 \times 6-12 \mu \mathrm{m}$ in diameter, single celled, hyaline, and elliptic or oval. The pycniospores are elliptical, thin walled, hyaline, and measure 10-42 x 6-10 $\mu \mathrm{m}$. Micro sclerotia of fungus are jet black in colour and appear smooth and round to oblong or irregular. Colonies in culture range in colour from white to brown or gray and darken with age. Hyphal branches generally form at right angles to parent hyphae, but branching is also common at acute angles. The fungus is greatly influenced by environmental factors and produces the pycnidia when the atmospheric temperature ranges of $25^{\circ} \mathrm{C}$ to $35^{\circ} \mathrm{C}$. The fungus survives in the form of sclerotia in soil and crop residues and also been reported to be seed born. The available literature revealed that not much research work is carried out on sesame disease in Madhya Pradesh particularly on root and stem rot.

\section{Material and Methods}

2.1 Influence of climate change on foliar disease of sesame

This experiment was conducted using susceptible variety VRI-1 and sown different date of interval on 1/8/17, 11/8/17 and 21/8/17 with three replications. The severity of root and stem rot was recorded at weekly intervals using 0-10 scale.

Weather observation obtained from meteorological department JNKVV Jabalpur. Environmental condition prevailed during the course of disease development were examined. Wise multiple regression analysis were performed using computer facility available at JNKVV Jabalpur. Stepwise multiple regression analysis were performed to find out the subset of environmental variable viz-maximum temperature, minimum temperature relative humidity

(morning), relative humidity (evening) and total rainfall and no of rainy days for the purpose of forecasting. The Per cent disease incidence of root and stem rot was recorded at weekly interval.

The incidence was co-related with the weather parameter Viz; maximum temperature, minimum temperature relative humidity (morning), relative humidity (evening) sand total rainfall and no of rainy days prior to seven disease observation was use for correlation and regression analysis evaluations of sesame variety against $M$. phaseolina under field condition.

\subsection{Statistical analysis}

Year and season of Experiment: Kharif 2017

\section{(I) Correlation coefficient:}

Correlation and regression between percent disease index and meteorological parameters were worked out:

$$
r(x y)=\frac{\operatorname{COV} .(x y)}{\sqrt{\text { Var. }(x) \operatorname{Var} .(y)}}
$$

Where,

$\mathrm{r}(\mathrm{xy}=$ correlation coefficient between character $\mathrm{x}$ and $\mathrm{y}$. COV $(x y)=$ covariance between character $\mathrm{x}$ and $\mathrm{y}$.

$\mathrm{V}(\mathrm{x})=$ variance of $\mathrm{x}$ character.

$\mathrm{V}(\mathrm{y})=$ variance of $\mathrm{y}$ character

\section{Test of Significance of " $r$ "}

$$
\mathrm{t}=\frac{\mathrm{r}}{\sqrt{1-r 2}} \sqrt{n-2}
$$

\section{Where}

$\mathrm{r}=$ correlation coefficient

$\mathrm{n}=$ Number of observations

$\mathrm{df}=(\mathrm{n}-2)$

\section{(ii) Analysais of variance- Randomized Complete Block Design}

The data were subjected to statistical analysis after tabulation. The data were transformed to their angular values as required. The data so obtained were analyzed by using the analysis of variance technique as given below:

Table 1: ANOVA for Randomized Complete Block Design

\begin{tabular}{|c|c|c|c|c|c|}
\hline $\begin{array}{c}\text { Sources of } \\
\text { variance }\end{array}$ & d.f & S.S. & M.S.S. & $\begin{array}{c}\text { F } \\
\text { Cal }\end{array}$ & F Table \\
\hline Replications & $(\mathrm{r}-1)$ & SSR & SSR/r-1=a & $\mathrm{a} / \mathrm{c}$ & \\
\hline Treatments & $(\mathrm{t}-1)$ & $\mathrm{SST}$ & $\mathrm{SST} / \mathrm{t}-1=\mathrm{b}$ & $\mathrm{b} / \mathrm{c}$ & $\begin{array}{c}\text { F at 5\% }(\mathrm{t}-1), \\
(\mathrm{r}-1)(\mathrm{t}-1)\end{array}$ \\
\hline Error & $(\mathrm{r}-1)(\mathrm{t}-1)$ & $\mathrm{SSE}$ & $\mathrm{SSE} /(\mathrm{r}-1)(\mathrm{t}-1)=\mathrm{c}$ & - & - \\
\hline Total & $(\mathrm{r} \times \mathrm{t}-1)$ & - & - & - & - \\
\hline
\end{tabular}

Where,

$\begin{array}{ll}\mathrm{r} & =\text { number of replications } \\ \mathrm{t} & =\text { number of treatments } \\ \mathrm{SSR} & =\text { Replication mean sum of square } \\ \mathrm{SST} & =\text { Treatment mean sum of square } \\ \mathrm{SSE} & =\text { Error mean sum of square } \\ \text { d.f } & =\text { Degree of freedom }\end{array}$

The significance among different treatment means was judged by critical difference (CD) at 5\% level of significance for comparison among the treatments, for which the marginal means of each treatment was considered. The following formula was used for various estimations.

1. $S E m \pm=\sqrt{E M S / r}$

2. Critical difference $(C D)=\operatorname{SEm} \times \sqrt{2} \times \mathrm{t}$ at 0.05

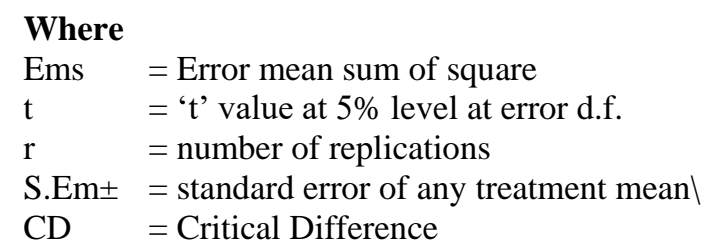

(iii) Completely Randomized Design (CRD)

Table 2: ANOVA for CRD

\begin{tabular}{|c|c|c|c|c|}
\hline $\begin{array}{c}\text { Source of } \\
\text { Variation }\end{array}$ & $\begin{array}{c}\text { Degree of } \\
\text { Freedom }\end{array}$ & $\begin{array}{c}\text { Sum of } \\
\text { Squares }\end{array}$ & $\begin{array}{c}\text { Mean } \\
\text { Squares }\end{array}$ & $\begin{array}{c}\text { F- } \\
\text { Calculated }\end{array}$ \\
\hline Treatment & $t-1$ & $S S T$ & $S S T / t-1$ & $M S T / M S E$ \\
\hline Error & $t(r-1)$ & $S S E$ & $S S E / t(r-1)$ & \\
\hline Total & $(r t-1)$ & & & \\
\hline
\end{tabular}

$S E m \pm=\sqrt{E M S / r}$
$S E d \pm=\sqrt{2 E M S / r}$
$C D=S E d \pm \times$ tat $5 \%$

Where,

$r=$ No. of replication

$E M S=$ Error mean square

$S E m \pm=$ Standard error of treatment mean

$S E d \pm=$ Standard error of difference to two treatment mean

$C D=$ Critical difference to two treatments mean 


\subsection{Meteorological data}

The weather condition during the course of studies from September, 2017 presented in table

Table 3: Meteorological data during the crop season of 2017-18 at Jabalpur

\begin{tabular}{|c|c|c|c|c|c|c|c|c|}
\hline \multirow{2}{*}{ Month } & \multirow{2}{*}{ Date of observation } & \multirow{2}{*}{ SMW } & \multicolumn{2}{c|}{ Temperature } & \multirow{2}{*}{ Rain fall (mm) } & \multirow{2}{*}{ No. of rainy Days } & \multicolumn{2}{c|}{ Relative Humidity } \\
\cline { 5 - 6 } & & & Max. & Min. & & & Morning & Evening \\
\hline Sept & 1SEP-7SEP & 36.0 & 32.5 & 24.0 & 15.0 & 0.0 & 88.0 & 65.0 \\
\hline Sept & 8SEP-14SEP & 37.0 & 32.8 & 23.3 & 87.8 & 2.0 & 91.0 & 64.0 \\
\hline Sept & 15SEP-21SEP & 38.0 & 30.7 & 22.4 & 98.3 & 3.0 & 90.0 & 73.0 \\
\hline Sept & 22SEP-28SEP & 39.0 & 32.9 & 21.9 & 0.0 & 0.0 & 89.0 & 52.0 \\
\hline Oct & 29SEP-5SEP & 40.0 & 33.4 & 20.3 & 7.4 & 1.0 & 90.0 & 51.0 \\
\hline Oct & 06OCT-11OCT & 41.0 & 32.6 & 21.7 & 9.2 & 1.0 & 92.0 & 56.0 \\
\hline Oct & 13OCT-18OCT & 42.0 & 33.6 & 17.9 & 0.0 & 0.0 & 87.0 & 40.0 \\
\hline Oct & 20OCT-25OCT & 43.0 & 33.1 & 15.9 & 0.0 & 0.0 & 81.0 & 26.0 \\
\hline Nov & 27OCT-1OCT & 44.0 & 31.1 & 12.2 & 0.0 & $0 . .0$ & 87.0 & 29.0 \\
\hline Nov & 3NOV-8NOV & 45.0 & 30.0 & 10.2 & 0.0 & 0.0 & 86.0 & 27.0 \\
\hline Nov & 10NOV-15NOV & 46.0 & 28.9 & 11.9 & 0.0 & 0.0 & 87.0 & 42.0 \\
\hline
\end{tabular}

Source: Meteorological observatory, College of Agriculture Jnkvv, Jabalpur (M.P.)

\section{Results}

\subsection{Disease development in relation to environmental} factors: This experiment was conducted using susceptible variety VRI-1 and sown three different date of sowing. Data presented in the (Table 4) indicate that maximum disease incidence $(38 \%)$ was recorded in second date of sowing and minimum $(33 \%)$ in first date.

Table 4: Effect of date of sowing for root and stem rot disease incidence of sesame

\begin{tabular}{|c|c|c|c|}
\hline \multirow{2}{*}{ Date of observation } & \multicolumn{3}{|c|}{ Percent disease incidence (\%) } \\
\cline { 2 - 4 } & DOS 1.08.17 & DOS 11.08.17 & DOS 21.08.17 \\
\hline 01.09 .17 & 2.5 & 0.0 & 0.0 \\
\hline 08.09 .17 & 5.0 & 1.0 & 3.0 \\
\hline 15.09 .17 & 10.6 & 2.0 & 5.0 \\
\hline 22.09 .17 & 15.5 & 3.3 & 6.6 \\
\hline 29.09 .17 & 20.3 & 9.2 & 13.3 \\
\hline 06.10 .17 & 22.0 & 10.3 & 15.6 \\
\hline 13.10 .17 & 25.5 & 11.0 & 27.8 \\
\hline 20.10 .17 & 27.0 & 24.0 & 22.2 \\
\hline 27.10 .17 & 28.0 & 30.3 & 26.2 \\
\hline 03.11 .17 & 31.2 & 36.6 & 30.4 \\
\hline
\end{tabular}

DOS $=($ Date of sowing $)$

The weather condition during to meteorological week were observed to the most congeneal for the crop infection and further rapid buildup of the disease. The rate of disease build up was correlated with the weather parameter during the crop growth for three date of sowing (Table 5). All the three date of sowing and meteorological factor $\mathrm{Viz}$. Maximum temperature $(\mathrm{x} 1)$ minimum temperature $(\mathrm{x} 2)$ rainfall $(\mathrm{mm})$ (x3) no of rainy days (x4) relative humidity morning (x5) relative humidity evening $(\mathrm{x} 6)$ showed a negative correlation with the disease development 34.

The disease was negatively correlated with first date of sowing (1/8/2017) temperature maximum ( $\mathrm{r}=-0.43)$, minimum $\left(\mathrm{r}=-0.888^{* *}\right)$ rain fall $\left(\mathrm{r}=-0.655^{*}\right)$ no of rainy days $(\mathrm{r}=-$ $0.527)$ relatively humidity morning $(\mathrm{r}=-0.505)$ and evening $\left(\mathrm{r}=-0.850^{* *}\right)$ Second date of sowing $(11 / 8 / 2017)$ temperature maximum $(\mathrm{r}=-0.659 *)$ minimum $(\mathrm{r}=-0.978 * *)$ rain fall $(\mathrm{r}=-$ $0.532)$ no of rainy days $(r=-0.523)$ relatively humidity morning ( $\mathrm{r}=-0.575)$ and evening $(\mathrm{r}=-0.827 * *)$ and third date of sowing (21/8/2017) temperature maximum ( $r=-0.577)$, minimum $(\mathrm{r}=-0.954 *)$ rain fall $(\mathrm{r}=-0.579)$, no of rainy days $(\mathrm{r}=-0.515)$, relatively humidity morning $(\mathrm{r}=-0.517)$ and evening $\left(\mathrm{r}=-0.827^{* *}\right)$. This is clearly indicated that weather parameter play a crucial role in the root and stem rot disease development. Stepwise multiple regression analysis showed that predicated mean percent disease incidence of root and stem rot was greatly infection influenced by the variable. Viz. Maximum temperature (x1) minimum temperature (x2) rainfall $(\mathrm{mm})(\mathrm{x} 3)$ no of rainy days $(\mathrm{x} 4)$ relative humidity morning (x5) relative humidity evening (x6). Multiple regression equitation percent disease incidence and various exhibited strongly relationship among different component of the epiphytotics during all the date of sowing (Table no. 6). The R2 value of function ranged from 0.94 to 0.99 , the line prediction equation for root and stem rot first date of sowing $\mathrm{Y}=48.97+(0.47 \mathrm{x} 1)+(-1.67 \mathrm{x} 2)+(-0.27 \mathrm{x} 3)+(8.76 \mathrm{x} 4)+(-$

$0.13 \times 5)+(-0.04 \times 6) \quad Y=170.25+\quad(-3.55 \times 1)+(-1.05 \times 2)+(-$ $0.09 \times 3)+(2.58 \times 4)+(-0.06 \times 5)+(-0.36 \times 6)$ and $\mathrm{Y}=64.31+$ $0.13 \times 1)+(-2.25 \times 2)+(-0.18 \times 3)+(5.11 \times 4)+(-0.07 \times 5)+(0.08 \times 6)$ were selected as the best fit for predicting the disease under normal epiphytotics.

Table 5: Simple correlations for sesame root and stem rot disease

\begin{tabular}{|c|c|c|c|}
\hline \multirow{2}{*}{ Weather parameters } & \multicolumn{3}{|c|}{ Per cent disease incidence (\%) } \\
\cline { 2 - 4 } & D/S 1.08.17 & D/S 11.08.17 & D/S 21.08.17 \\
\hline Tem (MAX) & -0.430 & $-0.659^{*}$ & -0.577 \\
\hline Tem (MIN) & $-0.888^{* *}$ & $-0.978^{* *}$ & $-0.954^{* *}$ \\
\hline Rainfall (mm) & $-0.655^{*}$ & -0.532 & -0.579 \\
\hline No of rainy days & -0.527 & -0.523 & -0.515 \\
\hline RH(M) & -0.505 & -0.575 & -0.517 \\
\hline RH(E) & $-0.850^{* *}$ & $-0.827 * *$ & $-0.827 * *$ \\
\hline
\end{tabular}

Correlation is significant at the 0.05 level $* *$

Correlation is significant at the 0.01 level

Table 6: Multiple regression equitation between weather parameter on root and stem rot disease

\begin{tabular}{|c|c|c|c|}
\hline Disease index & $\begin{array}{c}\text { Correlation } \\
\text { Coefficient (R) }\end{array}$ & $\begin{array}{c}\text { Coefficient of multiple } \\
\text { determination on R2 }\end{array}$ & Multiple regression equitation \\
\hline DOS $(01.08 .17)$ & 0.97 & 0.94 & $\mathrm{Y}=48.97+(0.47 \times 1)+(-1.67 \times 2)+(-0.27 \times 3)+(8.76 \times 4)+(-0.13 \times 5)+(-0.04 \times 6)$ \\
\hline DOS $(11.8 .17)$ & 0.97 & 0.94 & $\mathrm{Y}=170.25+(-3.55 \times 1)+(-1.05 \times 2)+(-0.09 \times 3)+(2.58 \times 4)+(-0.06 \times 5)(-0.36 \times 6)$ \\
\hline DOS $(21.8 .17)$ & 0.97 & 0.94 & $\mathrm{Y}=64.31+(-0.13 \times 1)+(-2.25 \times 2)+(-0.18 \times 3)+(5.11 \times 4)+(-0.07 \times 5)+(0.08 \times 6)$ \\
\hline
\end{tabular}

$\mathrm{Y}=$ predicated mean disease severity, $\mathrm{X} 1=$ Maximum temperature, $(\mathrm{x} 2)=$ minimum temperature, $(\mathrm{x} 3)=$ rainfall $(\mathrm{mm}),(\mathrm{x} 4)=$ no of rainy days, $(\mathrm{x} 5)=$ relative humidity morning, $(\mathrm{x} 6)=$ relative humidity evening, $\mathrm{R} 2=$ regression square . 


\section{Discussion and Conclusion}

\subsection{Disease development in relation to environmental factor}

The development of root and stem rot intensity was studies in relation to various climatic parameters viz., First date of sowing (1/8/2017) temperature maximum $(\mathrm{r}=-0.43)$, minimum $\left(\mathrm{r}=-0.888^{* *}\right)$, rain fall $\left(\mathrm{r}=-0.655^{*}\right)$, number of rainy days $(\mathrm{r}=-0.527)$, relatively humidity morning $(\mathrm{r}=-$ $0.505)$ and evening $\left(\mathrm{r}=-0.850^{* *}\right)$, Second date of sowing $(11 / 8 / 2017)$ temperature maximum $(r=-0.659 *)$ minimum $(r$ $=-0.978 * *)$ rain fall $(\mathrm{r}=-0.532)$ no of rainy days $(\mathrm{r}=-$ $0.523)$ relatively humidity morning $(\mathrm{r}=-0.575)$ and evening $(\mathrm{r}=-0.827 * *)$ and third date of sowing (21/8/2017), temperature maximum ( $\mathrm{r}=-0.577)$, minimum $(\mathrm{r}=-0.954 *)$ rain fall $(\mathrm{r}=-0.579)$, no of rainy days $(\mathrm{r}=-0.515)$, relatively humidity morning $(\mathrm{r}=-0.517)$ and evening $\left(\mathrm{r}=-0.827^{* *}\right)$. Six regression coefficients were obtained for independent variables viz., Maximum temperature $\left({ }^{\circ} \mathrm{C}\right)$, minimum temperature $\left({ }^{\circ} \mathrm{C}\right)$ rain fall $(\mathrm{mm})$ number of rainy days and relative humidity (\%) as the dependent variable disease incidence. Multiple regression equitation percent disease incidence and exhibited relationship between different component of the epiphytotics during all the date of sowing studied and combine effect of different weather variation favored disease development causing up to 99 percent variation in disease index (Table no.4) the R2 value of function ranged from 0.94 to 0.99 the line prediction equation for root and stem rot first date of sowing first DOS $\mathrm{Y}=48.97+(0.47 \times 1)+(-1.67 \times 2)+(-0.27 \times 3)+(8.76 \times 4)+(-$ $0.13 \times 5)+(-0.04 \times 6) \quad$ Second DOS $Y=170.25+(-3.55 \times 1)+(-$ $1.05 \times 2)+(-0.09 \times 3)+(2.58 \times 4)+(-0.06 \times 5)(-0.36 \times 6)$ and third DOS $\mathrm{Y}=64.31+(-0.13 \times 1)+(-2.25 \times 2)+(-0.18 \times 3)+(5.11 \times 4)+(-$ $0.07 \times 5)+(0.08 \times 6)$ were selected as the best fit for predicting the disease under normal epiphytotics found to have a significant negative correlation Based on the regression coefficients obtained for root and stem rot disease, linear equations were derived to predict the disease depending upon weather conditions prevailing during crop season. The present findings are similar with the results of Satpathi and Gohel $(2018)^{[9]}$ who reported higher temperature $\left(35^{\circ} \mathrm{C}\right)$ and low relative humidity to be favorable for maximum disease incidence of charcoal rot of sesame ( $M$. phaseolina). Similar results were also obtained by Deepthi et al. (2014) ${ }^{[3]}$ for blight of green gram caused by $M$. phaseolina which maximum disease incidence was found in the month.

Root and stem rot intensity was higher in all the three dates of sowing. Correlation of root and stem rot with the weather parameters indicated that root and stem rot negative relationship with all the weather parameter Viz. Maximum temperature, minimum temperature, rainfall $(\mathrm{mm})$, no of rainy days, relatively humidity (morning and evening).

\section{Acknowledgement}

The authors express thanks to Department of Plant Pathology, College of Agriculture, Jabalpur, Jawaharlal Nehru Krishi Viswavidyalaya, Jabalpur for providing all the facilities to conduct work.

\section{References}

1. Avila J, Aponte O, Pineda J, Colmenares. The cultivation of sesame. FONAIAP Publication series, Araure Venezuela. Centre of lnvestigaciones of Portuguesa state 1999, 83.

2. Das IK, Fakrudia B, Arora DK. RAPD cluster analysis and chlorate sensitivity of some Indian isolates of
Macrophomina phaseolina from sorghum and their relationships with Pathogenicity. Microbial. Res 2008;163:215-224

3. Deepthi P, Shukla CS, Verma KP, Reddy SS. Yield loss assessment and influence of temperature and relative humidity on charcoal rot development in sesame (Sesamum indicum L.) 2014;9(1):193-195.

4. Dinakaran D, Mohammed N. Identification of resistant sources to root rot of sesame caused by Macrophomina phaseolina (Tassi.) Goid. Sesame and Safflower Newsletter 2001;16:68-71.

5. Gupta KN, Naik KR, Bisen R. Status of sesame diseases and their integrated management using indigenous practices. International Journal of Chemical Studies 2018;6(2):1945-1952.

6. Menezes M, Oliveira SA. Fungos fitopatogenicos. Recife: UFRPE, 1993, 277.

7. Mukharji KG, Bhasin J. Plant disease in India. Today and Tomorrow Publisher. New Delhi 1986.

8. Rajput MA, Khan ZH Jafr KA, Fazal Ali JA. Field screening of sesame germplasm for resistance against charcoal rot (Macrophomina phaseolina). Sesame and Safflower Newsletter 1998;13:63-66.

9. Satpathi AK, Gohel NM. Role of meteorological factors on development of stem and root rot of sesame. Journal of Pharmacognosy and Phytochemistry 2018;7(6):19221924.

10. Vyas SC, Patel MC. Integrated biological and chemical control of dry root rot of chickpea. Indian J Mycol. Pl. Pathol 2015;24(2):132-34. 